4. Потяг до навчального спілкування на основі розвитку почуття співдружності 3 однокласниками, що виявляється у прагненні брати участь у спільних справах.

У публікації розкрито тенденції розвитку краєзнавчої освіти у змісті методичних рекомендацій для вчителів ЗОШ із формування творчої активності учнів основної школи у процесі туристсько-краєзнавчої роботи (самостійний культурно-освітній напрям у складі освітянської галузі; чинник здійснення діяльності перетворювальної, пізнавальної, цілісно-орієнтаційної, спілкування, художньої, що сприяє вияву творчого потенціалу особистості). Розкриття закономірностей розвитку краєзнавчої освіти 3 метою іiі ефективного управління та прогнозування стратегії розвитку, стає можливим лише за умови пізнання природи, суті, функцій, структури краєзнавчої освіти в цілому.

\title{
Література
}

1. Анохин П. К. Избранные труды: Философские аспекты теории функциональной системы / П. К. Анохин. - М. : Наука, 1978. - 400 с. 2. Каган М. С. Системный подход и гуманитарное знание : Избранные статьи / М. С. Каган. - Л. : Изд-во Ленин. ун-та, 1991. - 384 с. З. Леднев В. С. Содержание образования: сущность, структура, перспективы / В. С. Леднев. - М. : Высш. шк., 1991. - 224 с. 4. Луговий В. І. Педагогічна освіта в Україні / В. І. Луговий. - К. : МАУП, 1994. 196 с. 5. Макареня А. А. Методологические основы создания культуротворческой среды подготовки учителя : автореф. дис. на стискание ученой степени докт. пед. наук : 13.00.01/ А. А. Макареня. - М., 1998. - 42 с. 6. Оконь В. Введение в общую дидактику / В. Оконь / [пер. с польского Л. Г. Кашкуревича, Н. Г. Горина]. - М. : Высш.шк., 1990. - 382 с. 7. Педагогика : [учебное пособие для студентов пед. ин-тов] / Ю. К. Бабанский, В. А. Сластенин, Н. А. Сорокин и др. / под ред. Ю. К. Бабанского. - М. : Просвещение, 1988. -479 с. 8. Подласый И. П. Педагогика : [учебник для студ. высш. учеб. завед.] / И. П. Подласый. - М. : Просвещение, 1996. - 432 с. 9. Український радянський енциклопедичний словник : в 3 т. / ред. кол. : Бабичев К. С., Дзеверін І. О., Денисов А. Ф. та ін. - Т.2. - К. : УРЕ, 1987. - С. 59.

УДК 78(07):373.5

Т. Д. Фурдак, ст. викладач,

Криворізький педагогічний інститут ДВНЗ «Криворізький наиіональний університет»

\section{СУТНІСТЬ ТА ОСОБЛИВОСТІ МУЗИЧНОГО СПРИЙМАННЯ УЧНІВ НА УРОКАХ МУЗИки}

Фурдак Т. Д. Сутність та особливості музичного сприймання учнів на уроках музики.

У статті грунтовно розкрито сутність та особливості музичного сприймання учнів на уроках музики. На основі теоретичного аналізу досліджень науковців, багаторічного особистого спостереження, досвіду викладачів вищих навчальних закладів та вчителів музики загальноосвітніх шкіл пропонуються етапи організації умов процесу вміння усвідомлено сприймати музичний твір учнями.

Ключові слова: музичне сприймання, емоційно-свідоме сприймання, пізнання, пізнавальний інтерес.

Фурдак Т. Д. Сущность и особенности музыкального восприятия учеников на уроках музыки.

В статье расскрыта сущность и особенности музикального восприятия учеников на уроках музыки. На основании теоретического анализа исследований учених, личных многолетних наблюдений, опыта педагогов высших учебных заведений, a также учителей общеобразовательных школ предлагаются этапы организации условий процесса умения сознательно воспринимать музыкальное произведение учениками.

Ключевые слова: музыкальное восприятие, эмоционально-сознательное восприятие, познание, познавательный интерес.

Furdak T. D. Essence and features musical perception of pupils in music. 
The article thoroughly essence and features musical perception by pupils for music lessons. Based on the theoretical analysis of the investigations, experience university professors and teachers of music schools offer stages of the process ability to consciously perceive music students.

Key words: musical perception, emotional and conscious perception, cognition, cognitive interest.

Музика є результатом людської діяльності, містить не тільки те, що перебуває поза людиною, але й особистісні зміни фізичного і духовного обличчя, або сприяє утворенню цілого світу людського життя, який народжується разом з людиною, росте, стає багатшим, змістовнішим, впливає на його характер, вчинки і вигляд. Цей вид мистецтва, особливо для дитини, є дверима до якоїсь нової реальності, шляхом у невідоме.

Музика $\epsilon$ одним із наймогутніших засобів виховання, що надає естетичного забарвлення всьому духовному життю людини. Проте, уміння слухати й чути музику не $\epsilon$ вродженою якістю.

Mema cmammi - розкрити етапи організації процесу вміння усвідомлено сприймати музичний твір учнями на уроках музики в загальноосвітній школі.

Кожний учитель, на думку Н. Тализіної, підкреслює, що має програму тих предметних знань, яким він повинен навчити учнів. Але з жодного предмета немає конкретної програми вмінь, за допомогою яких учень повинен вміти використовувати набуті знання. Вчителю необхідно чітко уявляти зміст тих прийомів, умінь пізнавальної діяльності, яким навчаються учні: «Без цього вчитель не може цілеспрямовано формувати накреслену пізнавальну діяльність... Водночас, виокремлення змісту кожного виду (прийому) пізнавальної діяльності - це особлива задача, нерідко - дослідницька» [5].

Як предмет дослідження, пізнання - це сукупність процесів, процедур і методів набуття знань про явища і закономірності об’єктивного світу. Пізнання є основним предметом науки гносеології; вищою формою відображення об'єктивної дійсності; процесом вироблення дійсних знань. У пізнанні виокремллють два рівні: чуттєве пізнання, здійснюється за допомогою відчуття, сприйняття, уявлення (сенсуалізм), і раціональне пізнання, що протікає в поняттях, думках, висновках і фіксується в теоріях (раціоналізм). Різні аспекти процесу пізнання досліджуються низкою спеціальних наук: когнітивною психологією, історією науки, соціологією науки тощо.

Наявність пізнавальних інтересів суттєво впливає на становлення почуттів як мотивів формування навчальної діяльності, володіння учнями на уроках музики інтелектуальними уміннями, потреби сприймання, розуміння музичних творів, а також формування музичної культури та музичного смаку, що, зумовлено багатьма психологічними та педагогічними чинниками.

Вважаємо, що пізнавальні інтереси розвиваються в активному процесі 3 умінням сприймати музичний твір, який містить досвід безпосередніх переживань і роздумів, що формується під впливом музичного мистецтва, а також художній досвід, пов'язаний із слуханням музики. Це надає змогу розглядати сприймання як основу засвоєння школярами втіленого в музиці досвіду естетичного ставлення до дійсності. Тому головним завданням музичного виховання учнів, формування пізнавального інтересу на уроках музики $\epsilon$ формування в них активного, усвідомленого сприймання музичних творів, що робить цей процес не просто необхідним, але й привабливим у певному розумінні. Однак якщо в процесі навчання ця установка не буде підкріпленою іще й іншими мотивувальними чинниками, то вона не забезпечить максимального ефекту, оскільки має привабливість не діяльність як така, а лише те, що пов'язане з нею.

Свого часу Б. Теплов зазначав, що художньо-повноцінне сприймання мистецтва - це активна діяльність, мало того «вміння», якому необхідно вчитися. Виховуючи вміння «бачити» $\mathrm{i}$ «чути», мистецтво створює передумови для поширеного пізнання світу [6].

Різностороннє вивчення сприймання показало, що як і всякий процес пізнання, воно залежить від особливостей суб'єкта: установок, досвіду, знань, потреб, інтересів, спрямованості, прагнення, сподівання. Як і відчуття, воно є суб'єктивним образом 
об’єктивної дійсності. Тому у сприйманні виявляється ставлення людини до об'єкта, iї бажання, інтереси, почуття тощо.

Критичний аналіз таких поглядів здійснили в роботах психологи С. Рубінштейн, О. Леонтьєв, П. Гальперін та ін. На їхню думку сприймання потрібно розглядати як своєрідну дію, спрямовану на обстеження об'єкта сприймання i на створення його подібності.

Провідною проблемою сучасної музичної педагогіки $\epsilon$ формування музичного сприймання учнів. Розвиток окресленої мисленнєвої операції $\epsilon$ одним із найвідповідальніших завдань на уроці музики в загальноосвітній школі, центральною проблемою музично-естетичного виховання.

«Перш ніж ти хочеш залучити дитину до якоїсь діяльності, - писав Л.Виготський зацікав її нею, потурбуйся про те, щоб виявити, що вона готова до цієї діяльності, що в неї напружені всі сили, необхідні для цього, і що дитина діятиме сама, вчителеві ж лишається тільки керувати й спрямовувати цю діяльність» [3, с. 118]. Саме установка на сприймання музики є важливою умовою формування музичного сприймання учнів.

Перебуваючи в колі посиленого інтересу представників різних галузей наук, проблема музичного сприймання вивчається відповідно в різних аспектах.

Так, сучасні дослідження сутності музичного сприймання спираються на грунтовні музикознавчі, психолого-педагогічні праці Ю. Алієва, Б. Асаф'єва, Л. Виготського, M. Кагана, О. Костюка, В. Медушевського, Е. Назайкінського, О. Ростовського, О. Рудницької, А. Сохора, Р. Тельчарової.

Згідно 3 педагогічною концепцією Б. Асаф'єва, Д. Кабалевського, в основі спостерігання музики лежить повноцінне іï сприймання. «Спостерігати» мистецтво означає, насамперед - уміти сприймати його. Елементи музичної спостережливості, розвинена увага, потреба в естетичному аналізуванні твору, достатній рівень музичного сприймання.

Музична психологія виокремлює кілька стадій сприймання музики від початкового ознайомлення до логічного засвоєння й емоційного переживання http://uk.wikipedia.org/wiki/\%D0\%9C\%D1\%83\%D0\%B7\%D0\%B8\%D0\%BA\%D0\%B0

cite_note-21, а також виокремлює області свідомого і несвідомого під час сприймання музики http://uk.wikipedia.org/wiki/\%D0\%9C\%D1\%83\%D0\%B7\%D0\%B8\%D0\%BA\%D0\% B0 - cite_note-ReferenceA-22.

Сприймання та вплив музики перебувають у тісному взаємозв'язку з емоційною сферою людини. В музичній педагогіці проблема розвитку емоційно-свідомого сприймання музики в дітей уважається однією 3 найбільш складних і гострих. Вона широко висвітлена в роботах Б. Асаф’єва, І. Барвінок, Н. Гродзенської, Л. Кадцина, О. Костюка, В. Медушевського, Є. Назайкінського, В. Петрушина, О. Ростовського, О. Рудницької, Б. Теплова, Н. Ткачової та інших вітчизняних і зарубіжних науковців.

Уміння сприймати й розуміти музику, на думку науковців, не $\epsilon$ результатом вікового дозрівання дитини, а забезпечується цілеспрямованим вихованням і педагогічним керівництвом, яке полягає в тому, щоб допомогти дитині піднятися від посередньої емоційної реакції до ії можливого для даного віку усвідомлення.

Грунтуючись на вищеперерахованих дослідженнях науковців, досвіді викладачів вищих навчальних закладів та вчителів музики загальноосвітніх шкіл, можемо стверджувати, що задля створення умов сприймання музики учнем на уроках музики у школі вчитель повинен володіти грунтовними знаннями 3 педагогіки та психології, методикою викладання, історією та теорією музики, аналізом музичних творів та гармонією, володіти музичним інструментом, уміннями та навичками проведення вокально-хорової роботи, повинен мати музичний слух тощо.

Вищесказане надає підстави вважати, що процес уміння усвідомлено сприймати учнями музичних творів на уроках музики буде більш ефективним за таких умов: виконання твору вчителем або прослуховування музики на мультимедійних носіях; бесіда 
вчителя про прослухану музику зі спрямуванням уваги учнів, зацікавленням їх розповіддю про композитора; спрямування концентрації учнів на перегляді засобів музичної виразності, виявленні настрою, порівнянні твору з іншими, вже відомими, сприйняття окремих епізодів, виявленні головної ідеї твору, розумінні позиції автора; повторне прослуховування твору, з метою кращого запам'ятовування, збагачення новими спостереженнями на основі отриманого музичного досвіду на попередніх уроках; слухання музичного твору на подальших уроках з метою закріплення, порівняння його 3 новими творами, музичними образами; добір музичних зразків високої художньої якості, де особливу увагу необхідно приділяти українській музичній творчості.

Удосконалення процесу усвідомленого сприймання учнями музичних творів на уроках музики передбачає: застосування різноманітних форм і методів роботи, які сприяють усвідомленому сприйманню музичних творів на уроках музики; урахування досягнень музикознавчої науки та суміжних дисциплін і передового педагогічного досвіду; встановлення більш тісної взаємодії між учнем та вчителем музики як єдиної мети та результату успішного усвідомлення сприймання музичного твору учнями на уроках музики.

Зазначені умови процесу усвідомленого сприймання учнями музичних творів на уроках музики, на нашу думку, забезпечують результативність досліджуваного мисленнєвого процесу, представляють систему й ефективно діють за умови їх взаємозв'язку.

На уроках музики необхідно уникати вольового стилю керування процесом сприймання музичних творів; вплив на особистість учня необхідно посилювати емоційнонасиченим спілкуванням, добором високохудожнього музичного матеріалу, стимулюванням психічних процесів проблемними питаннями, ігровими завданнями.

Вакуум, який утворюється на уроках музики, сповна заповнюється після школи. Не маючи стійких сформованих музичних смаків, підлітки швидко опиняються під впливом низькопробної естрадної музики, стають легкою здобиччю шоу-бізнесу. Тому, на нашу думку, для цілеспрямованого керування процесом формування музичного сприймання учнями на уроках музики необхідно враховувати такі позиції: програми музичного виховання повинні бути пов'язані 3 сучасністю; формування музичного смаку починається з родини, тому вчителям музики слід більше уваги приділяти зв'язку 3 родиною; учні потребують цілеспрямованого керування процесом музичного сприймання: мультимедійні носії, музичні передачі, які пропонується переглядати дітям на TV повинні мати високохудожній, естетичний рівень; молодь прагне більше знати про музику, застосовувати іï в житті, за допомогою музики змінювати життя на краще, особливо це стосується життя на селі, в райцентрах; музика допомагає у розв'язанні особистісних конфліктних ситуацій, сприяє покращенню настрою, емоційного стану; класична музика використовується для прослухування в період релаксації, особливих життєвих подій, для самозаспоспокоєння, або підвищення життєвих сил; учні недостатньо залучені до кращих зразків класичної та сучасної музики, що виявляє їх низький загальнокультурний рівень; загальноосвітній школі треба більше приділяти уваги дозвіллю молоді; активно впливати на міське телебачення, радіопередачі, пропонуючи загальноосвітні музичні лекції; національному музичному мистецтву повинно приділятися більше уваги з боку освітніх закладів, педагогів, засобів масової інформації.

Отже, одне $з$ основних завдань загальноосвітньої школи - вчити учнів сприймати музичний твір як невід'ємну частину їхньої духовності, тобто формувати здатність до активного засвоєння і відтворення світу художніх цінностей. Адже в сучасних умовах суперечності між наявною музичною культурою підлітків і справжніми цінностями мистецтва дедалі збільшується і загрожує відчуженням молоді від його світової скарбниці. Тому формування усвідомленого сприймання музичного твору учнями на уроках музики це актуальне завдання музичної педагогіки й потребує подальшого вивчення. 


\section{Література}

1. Алиев Ю. Б. Настольная книга школьного учителя-музыканта / Юлий Багирович Алиев. М. : Гуманит. изд. центр ВЛАДОС, 2000. - 336 с. 2. Бочкарьов Л. Л. Проблема адекватності сприйняття музики / Л. Л. Бочкарьов // Музична психологія і психотерапія. - 2007. - № 3. 3. Выготский Л. С. Психология искусства / Лев Семенович Выготский. - М. : Искусство,1986. 320 с. 4. Кабалевский Д. Б. Педагогические размышления: избранные статьи и доклады /Дмитрий Борисович Кабалевский. - М. : Просвещение, 1986. - 336 с. 5. Талызина Н. Ф. Психология музыкальных способностей / Н. Ф. Талызина, О. П. Лобанова. - М. : Выс. шк., 2009. - 244 с. 6. Теплов Б. М. Пихология музыкальных способностей / Б. М. Теплов // Избранные труды в 2т. Т. 1. - М. : Педагогика, 1985. 7. Ткачова Н. П. Сприйняття музики у вихованні учнів загальноосвітньої школи. Теорія і методика мистецької освіти : [зб. наук. праць] / [Н. П. Ткачова ; ред. кол. О. П. Щолокова та ін.]. - К. : НПУ, 2000. - 181 с.

УДК 811.161.2(07)

Л. С. Цоуфал,

старший викладач,

Криворізький педагогічний інститут ДВНЗ «Криворізький начіональний університет»

\section{ВИДИ ВПРАВ ДЛЯ ПІДГОТОВКИ УЧНІВ ДО НАПИСАННЯ ТВОРІВ}

Цоуфал Л. С. Види вправ для підготовки учнів до написання творів.

У статті охарактеризовано твір як вид роботи з розвитку зв'язного мовлення, визначено види вправ для розосередженої підготовки учнів до написання творів.

Ключові слова: писемне мовлення, твір, види творів, підготовка до написання твору.

Цоуфал Л. С. Виды упражнений для подготовки учащихся к написанию сочинений.

В статье охарактеризовано сочинение как вид работы по развитию связной речи, определены виды упражнений для рассредоточенной подготовки учащихся к написанию сочинений.

Ключевые слова: письменная речь, сочинение, виды сочинений, подготовка к написанию сочинения.

Tsoufal L. S. Types of exercises to prepare students for writing essays.

The article described the composition as a form of work for the development of coherent speech, identify che tupes of exercises to prepare students dispersed to writing essays.

Key words: writing, essay, types of essays, preparing to write essays.

У сучасних умовах розвитку шкільної мовної освіти особливої актуальності набуває проблема формування в учнів умінь і навичок діалогічного й монологічного мовлення, оскільки успішність людини в задоволенні практичних потреб, реалізації професійних планів значною мірою залежить від здатності до ефективної комунікації. Метою навчання мови відповідно до замовлення суспільства $є$ виховання всебічно розвиненої, духовно багатої особистості, яка володіє уміннями і навичками вільно, комунікативно виправдано користуватися засобами рідної мови - іiі стилями, типами, жанрами в усіх видах мовленнєвої діяльності.

У чинній програмі з української мови для 5-9 класів, зокрема в мовленнєвій змістовій лінії, серед робіт з розвитку зв'язного мовлення чільне місце посідають твори - вид вправ, який передбачає самостійний виклад учнями думок, почуттів, суджень. У порівнянні 3 переказом твір - складніший вид роботи, оскільки передбачає створення висловлювання за певну тему без опори на текст-зразок, вимагає від учнів самостійності, активності, вираження в тексті особистого життєвого досвіду. Твір сприяє не лише реалізації навчальної, розвивальної, виховної функцій мови, а й підготовці учнів до активної комунікативної діяльності в різноманітних ситуаціях.

Як зазначає Т. Донченко, в учнівському творі виявляється все: мовленнєвий розвиток учнів, знання властивостей гарного мовлення, словниковий запас учня, володіння 